
Address: 139 Proskurivskogo Pidpillia St., Khmelnytskyi, 29013, Ukraine

E-mail: bilykvika@ukr.net

\title{
PECULIARITIES OF DESIGN COMPETENCE FORMATION IN FUTURE CLOTHING ENGINEERING EDUCATORS IN UKRAINE AND FOREIGN COUNTRIES
}

\begin{abstract}
The importance of engineering pedagogical education for the global labour market has been characterized. The peculiarities of modern engineering pedagogical education formation in foreign countries consisting in economy globalization, transition to a high quality education and international cooperation enhancing have been presented. The essence of clothing engineering educators' design competence being the professional's ability to provide educational process with didactic design and productive one with technical documentation for the garment manufacture in accordance with the production norms and standards has been revealed.

On the basis of regulations and national and foreign experience (the USA, Australia, South Africa, European countries etc.) in clothing engineering educators' training the peculiarities of future professionals' design competence formation as a constituent of professional competence has been clarified. Training of future professionals in "Professional Education" specialisation is the first stage in obtaining the engineereducator qualification (Eastern European countries). The second stage means gaining pedagogical qualification in vocational pedagogical educational establishments on the basis of obtained engineering qualification. The third stage consists in obtaining engineering and pedagogical qualification based on technical training according to the learning outcomes in International Society for Engineering Pedagogy that documents teachers' qualification and competence and registers them in the international register of engineering educators.

Key words: competence, design competence, engineer, engineering educator, engineering educator's design competence, foreign countries, learning outcomes, International Society for Engineering Pedagogy.

\section{INTRODUCTION}

The importance of engineering pedagogical education in the economic development of Ukraine and abroad is dramatically growing. This is due to the introduction of high-tech industry, labour market needs in qualified specialists. Considerable interest in the quality of engineering educators' training is caused by increasing needs of higher education institutions in highly qualified teaching staff. European countries have declared teacher education to be one of the European social model foundations (Авшенюк, 2011) aimed at professional training of future specialists for various industries. Unique among pedagogical specialties one can consider engineering pedagogical education (EPE) that combines two independent and yet interrelated and integrated components such as engineering and psychological and pedagogical ones. Therefore, future engineering educator should be trained in the subject field of professional activity corresponding to the training profile and professional pedagogy and psychology field.
\end{abstract}


The development of modern world engineering pedagogical education is connected with the following peculiarities: the transition to high quality education and training of future professionals to new conditions of modern production; economy globalization; international educational cooperation enhancing; high rates of new technologies development etc. According to its functional nature engineering pedagogical education is referred by scientists to pedagogical education, as engineers' training defined as its main subject enables graduates to work both in education and production (Коваленко, 2008). The duality of engineering pedagogical education means future professionals' perform functions related to both production and education. Based on the performed functions I. Kankovskyi describes future engineers' professional competence and identifies such components as the design, management, research, organization, inculturalism and control (Канковський, 2014).

Clothing engineering educators' training is topical under the conditions of social and economic development in foreign countries since there is a lack of qualified specialists in sewing production. Thus, design competence of clothing engineering educators directed at providing pedagogical and productive processes with relevant regulations, programs, plans and innovative projects, we consider as basic in the formation of future specialists' professional competence. However, peculiarities of future clothing engineering educators' design competence formation in Ukraine and foreign countries are not still studied within independent research.

THE AIM OF THE STUDY

The aim of the study is to characterize peculiarities of future clothing engineering educators' design competence formation in Ukraine and foreign countries

\section{THEORETICAL FRAMEWORK AND RESEARCH METHODS}

Problems of specialists' competence formation are the study subject of scientists such as K. Anderk, V. Baidenko, H. Bergman, G. Boden, P. Dubasenuk, R. Higerty, V. Huston, O. Kovalenko, G. Raven, L. Tarhan, Yu. Tatura, L. Useinova, I. Vasylieva, R. White and others. Design competence formation of future specialists is revealed in researches by Yu. Belov, N. Brukhanov, B. D'Ippolito, S. Dokuchaev, W. Ernst Eder, S. Ignatenko, M. Jenko, S. Khandani, S. Nechipor, V. Petruk, Cynthia L. Regan, A. Shchukanova and others.

For the purpose of the study a set of theoretical methods was used, namely analysis, synthesis and generalisation of scientific literature and regulations on the problems of future engineering educators' training; comparison was used to compare learning outcomes of design competence; generalization and prediction in formulating conclusions.

\section{RESULTS}

Under the conditions of today's globalization and integration processes in education, $\mathrm{N}$. Nychkalo indicates that issues of educational systems interrelation among different continents, their multidimensionality, comparability and mutual recognition of product, i.e. an individual prepared to energetic professional activity in different fields (Ничкало, 2010). The competence approach implementing into the system of higher education provides for its orientation at the development of future professional's personality and achievement of desired learning outcomes (competencies), promotes efficient comparison of academic degrees and training programs, thus increases the transparency of specialists' training and quantitative index of teachers and students' mobility.

There are different ways to obtain clothing engineering educator competence worldwide. For instance, in Ukraine and some Eastern European countries "Vocational education (by profile)" is included in the list of specialties, where future graduates are 
qualified as engineering educators after completing five-year study. In Ukraine specific in training engineering educators by the specialty "Professional education." (7.01010401) one can consider two interrelated specialisations within curriculum disciplines, namely pedagogical and engineering ones related to sewing field. In the current industry standard (Educational qualification characteristics of specialists by specialisation "Pedagogical education (0101), specialty "Professional Education" (7.01010401), training profile "Light industry products technology") are defined functions, typical tasks and skills that a graduate should possess. Learning outcomes on engineering and pedagogical design consist in future project elaboration by future specialist documented in the professional language. Design competence of engineering educator is the ability to provide professional pedagogical process through didactic design and productive process through technical documents on garment manufacture in accordance with the norms and standards of production.

The dual nature of EPE is founded in its very essence, although specialists of nonpedagogical specialties in Ukraine can obtain pedagogical qualification in professional pedagogical universities and academies, in case the requirements of the industry standard of higher professional pedagogical education concerning psychological and pedagogical training have been met.

There is another way to obtain engineering pedagogical education, though. Worldwide experience of engineering educators' training shows that pedagogical education can be obtained on the basis of technical training. For this matter in 1972 in Europe International Society for Engineering Education (IGIP) was founded, which unites scientific pedagogical community of 72 different countries. According to the learning outcomes IGIP assigns listeners the title of "European teacher of engineering disciplines", documents teachers' qualification and competence and register them in the international register of engineering educators (International Society for Engineering Pedagogy, 2015). Thus, engineering educators are ready to perform functions of didactic designing, namely develop training content, select means, forms and teaching methods appropriate for that matter.

B. Remaud, member of Commission of certified engineers (France), notes that general results of engineers' training internationally recognized must include engineering design (B. Remaud, 2013).

In the documents of Engineers Australia Accreditation Board an element of engineer's competence is the ability to systematic designing technological processes based on defined engineering problems (Engineers Australia accreditation board, 2015).

In the Accreditation of Higher Education Programmes UK Standard for Professional Engineering Competence designing at the Bachelor's degree is understood as the creation and development of economic viable product, process or system to meet specific needs. At the Master's level it is viewed as extensive experience and comprehensive understanding of the design processes and methodology, and the ability to apply and adapt them in unfamiliar situations; ability to create innovative design of product, systems, components or processes to meet new needs (The accreditation of higher education programmes UK Standard for Professional Engineering Competence, 2015).

Similarly but with some differences, the content of engineering design is considered in EUR-ACE Framework Standards for the Accreditation of Engineering Programmes (EUR-ACE Framework Standards for the Accreditation of Engineering Programmes, 2015) and in Engineering Council Of South Africa Standards and Procedures System (Engineering Council Of South Africa Standards and Procedures System, 2015). 
So, it is obvious that the design competence formation is significant for the content of clothing engineers' training. It should be noted that nowadays clothing engineers' training is carried out in higher educational establishments all over the world, after the completing Bachelor and Master's degrees. In particular, in the USA there are over 250 universities where clothing engineers are trained; there are over 10 in Canadian provinces; Oceania has 20, India has 55; in South Korea there are over 40 such higher educational establishments. The considerable amount of universities training clothing engineers is present in China, since the sewing industry is being actively developed there. In Europe as one of leading fashion centres, more that 100 higher educational establishments provide clothing engineers' professional training (Hegland,2010).

It is necessary to consider the results of design competence formation of clothing engineers as it is the object of our study. In the document of American Family and consumer sciences credentialing center "Fashion, textiles and clothes. Assessment and certification of competencies" components of design competence, as learning outcomes are formulated as follows: to explain how the fabric, its fibrous structure, texture, pattern and processing affect the appearance of the product; apply schemes and color theory to create and improve visual effects; use the elements and principles of design; use system of automatic clothes design; create fashion design taking into account environmental, psychological, technical, economic and other requirements; demonstrate the ability to use design technologies in fashion, textile and clothing (Fashion, Textiles, and Apparel, 2015). The analysis of Bachelor's in Clothing Design training (University of Canberra, Australia, 2015) has enabled to outline such results of design competence learning : include properties of fibres and fabrics in clothing design, create the design according to the product's idea based on appropriate methods and necessary documentation, use systems of automatic design and methods for designing processes of sewing production (Bachelor of Fashion (Apparel Engineering and Design). University of Canberra, Australia, 2015). The interpretation of results formation of professional Bachelors' in Engineering design competence in different European countries is rather similar. According to the analysis of professional Bachelors' in Design, Technology and Sewing Industry Management learning in South-West University "Neofit Rilski", Bulgaria the design competence can be interpreted as the ability to design sewing and textile items, develop constructive, technological and technical economic documentation using modern computer systems (South-West University "Neofit Rilski”, Bulgaria, 2015).

Professional Bachelor of production of clothes at the university of Lithuania (Utena University of Applied Sciences) is the ability to generalize information on modern trends; apply the principles of garments modeling design; study and characterize features of clothing materials for making clothes; develop design and technological documentation for a new model of garments (Professional bachelor of production of clothes. Utena University Of Applied Sciences, 2015).

\section{CONCLUSIONS}

To conclude design competence of future educating engineer consists in the specialist's ability to develop pedagogical and productive designs based on principles and methods of design. we would like to indicate peculiarities of world practice in forming design competence as a constituent of future clothing engineering educators' professional competence that can be conducted in such ways:

1) to obtain the qualification of clothing engineering educator as a result of training by specialisation "Professional Education", profile "Light Industry Products Technology" in Ukraine (in other Eastern European countries profile name can vary). 
2) to obtain the engineer qualification in higher educational establishment and additional pedagogical competence in professional pedagogical universities, institutes or academies.

3) to obtain qualification of engineering educator based on the technical training according to the results of learning outcomes in the International Organization for Engineering Pedagogy (IGIP), which provides training and professional development of teachers in different specialties.

Prospects for future research lies in defining criteria and indicators of clothing engineering educators' design competence and justifying pedagogical conditions of its formation.

\section{REFERENCES}

1. Bachelor of Fashion (Apparel Engineering and Design). University of Canberra, $\begin{array}{llll}\text { Australia. } & \text { (2015). } & \text { Retrieved } & 28.02 .2015\end{array}$ http://www.canberra.edu.au/coursesandunits/course?course_cd=257HG.

2. Engineers Australia accreditation board (2014). Retrieved 25.02.2015 from: http://www.engineersaustralia.org.au/sites/default/files/shado/Education/Program\%20Accre ditation/AMS\%20Engineering\%20Associate\%20(Competency\%20based)/140210_p05ea_s tage_1.pdf.

3. Engineering council of South Africa. Standard and procedures system. (2004). Retrieved 28.02.2015 from : //www.ecsa. co.za/RegisterDocuments/FileNames/(BSc(Eng))\%20\%20Bachelors\%20Of\%20Engineerin g\%20(BEng)\%20Programmes.pdf.

4. EUR-ACE Framework Standards for the Accreditation of Engineering Programmes. (2008). Retrieved 24.02.2015 from : http: // www. enaee.eu/wpcontent/uploads/2012/01/EUR-ACE_Framework-Standards_2008-110511.pdf.

5. Fashion, Textiles, and Apparel. Assessment and Certification Competencies. (2015). Retrieved 27.02.2015 from : http: //www.aafcs. org / res / Credentialing / prepac / Competency_Lists / fashion\% 20textiles\% 20and\% 20apparel\% 20competencies.pdf.

6. Hegland, J. E. (2010). Dress and fashion education: Design and business. In Eicher, J. B. (Editor in Chief), Encyclopedia of world dress and fashion, Volume X. Oxford: Berg.

7. International Society for Engineering Education. (2010). Retrieved 27.02.2015 from : http://www.igip.org.

8. Professional Bachelor in design, technology and management in the sewing industry. South-West University «Neofit Rilski», Bulgaria. (2015). Retrieved 27.02.2015 from : http://www.swu.bg/media/352216/info\%20pak_mtmshp_2013_eng.pdf

9. Professional bachelor of production of clothes. Utena University Of Applied Sciences. (2014). Retrieved 26.02.2015 from : http: // www.bachelorstudies.ru/профессиональный-бакалавр-производстводежды/Litva/UtenaUniversity-Of-Applied-Sciences/.

10. Remaud, B. (2013). European perspectives on the competences of engineering graduates. Engineering education, No 12, p. 11-17.

11. Textile and clothing production. Higher Education Professional Study Programme.University of Ljubljana, Slovenia. (2015). Retrieved 1.03.2015 from : http http://www.iat.p.lodz.pl/files/docs/zbornikNTF.pdf. 
12. The accreditation of higher education programmes UK Standard for Professional Engineering Competence. (2014). Retrieved 28.02.2015 from : http://www.engc.org.uk/ecukdocuments/internet/document\%20library /AHEP\%20Brochure .pdf.

13. Авшенюк, Н., Кудін, В., Огієнко, О. (2011). Модернізаиія педагогічної освіти в європейському та євроатлантичному освітньому просторі [Improvement of Pedagogical Education in the European and Euro-Atlantic educational space]. K. : Педагогічна думка, p. 232 (in Ukrainian).

14. Каньковський, I. (2014). Система професійної підготовки інжсенерівпедагогів автотранспортного профілю [System of engineering educators' professional training of auto transport profile]. Хмельницький : ФОП Цюпак А.А., р. 562 (in Ukrainian).

15. Коваленко, О. (2008). Інженерно-педагогічні кадри: нові вимоги сьогодення [Engineering pedagogical staff: new requirements of the present]. Проблеми інженерно-педагогічної освіти [Problems of engineering and pedagogical education], No 21, p. 8-17 (in Ukrainian).

16. Ничкало, Н. (2010). Науково-методичне забезпечення професійної освіти і навчання: прогностичний аспект [Scientific and methodological support of professional education and training: a prognostic aspect]. In: Науково-методичне забезпечення професійної освіти $і$ навчання: тези доповідей звітної науково-практичної конферениії (м. Київ, 29-31 березня 2010 р.) [Scientific and methodological support of professional education and training: abstracts of reporting scientific practical conference (m. Kyiv, 29-31 March 2010) / Institute of Professional Education of NAPS of Ukraine. К. : ІПТО НАПН України, p. 4-8 (in Ukrainian). 